\title{
Studi Morfometrik Kepiting Bakau (Scylla serrate) Forsskål, 1775 (Malacostraca : Portunidae) di Kecamatan Wedung, Demak, Jawa Tengah
}

\author{
Jakfar Shodiq Panatar*, Ali Djunaedi, Sri Redjeki \\ Departemen IImu Kelautan, Fakultas Perikanan dan IImu Kelautan, Universitas Diponegoro \\ JI. Prof. H. Soedarto S.H, Tembalang, Semarang, Jawa Tengah 50275 Indonesia \\ ${ }^{*}$ Corresponding author, e-mail: jakfarshodiq21@gmail.com
}

\begin{abstract}
ABSTRAK : Kepiting bakau (Scylla serrata) adalah jenis kepiting yang hidup di perairan pantai, tambak, dan hutan bakau (mangrove). Kepiting bakau (Scylla serrata) merupakan komoditas ekspor bernilai ekonomis tinggi yang sangat potensial untuk dikembangkan dan memiliki nilai ekonomis yang tinggi di Indonesia, terutama kepiting yang sudah dewasa serta gemuk. Tujuan penelitian ini adalah untuk mengetahui karakteristik morfometrik kepiting bakau (Scylla serrata) seperti kelimpahan relatif kepiting bakau (Scylla serrata), distribusi lebar karapas, dan hubungan lebar karapas - berat kepiting bakau (Scylla serrata). Analisis yang digunakan dalam penelitian ini yaitu kelimpahan realatif kepiting dan analisis regresi. Penelitian ini dilaksanakan pada bulan Februari - April 2019 di Kecamatan Wedung, Demak. Materi yang digunakan pada penelitian ini adalah sampel kepiting bakau (Scylla serrata) hasil tangkapan nelayan di daerah tersebut. Kepiting bakau hasil tangkapan nelayan tersebut dihitung jumlahnya, diidentifikasi jenis kelaminnya, diukur lebar karapas dan ditimbang beratnya. Hasil penelitian menunjukkan bahwa Kepiting bakau (Scylla serrata) yang tertangkap pada bulan Februari - April 2019 diperoleh 300 individu yang terdiri dari 202 jantan dan 98 betina. Rata - rata ukuran lebar karapas tertinggi berkisar $9.8 \mathrm{~cm}$ pada hasil tangkapan di bulan Februari. Hubungan lebar karapas - berat Kepiting bakau (Scylla serrata) baik jantan maupun betina menunjukkan pola pertumbuhan allometrik negatif.
\end{abstract}

Kata kunci : Hubungan lebar karapas - berat; morfometrik; Scylla serrata

\section{Morphometric Study of Giant Mud Crab (Scylla serrata) Forsskål, 1775 (Malacostraca:Portunidae) in Wedung Districk, Demak, Central Java}

\begin{abstract}
Giant mud crab (Scylla serrata) are types of crabs that live in coastal waters, ponds, and mangrove forests. Giant mud crab (Scylla serrata) is a high economic value export commodity that has the potential to be developed and has high economic value in Indonesia, especially crabs that are mature and fat. The purpose of this study was to determine the morphometric characteristics of giant mud crab (Scylla serrata) such as relative abundance of giant mud crab (Scylla serrata), carapace width distribution, and the relationship between carapace width - weight of giant mud crab (Scylla serrata). The analysis used in this study is the relative abundance of giant mud crab and regression analysis. This research was conducted in February - April 2019 in the subdistrict of Wedung, Demak. The material used in this study was a sample of giant mud crab (Scylla serrata) from the fishermen catch in the area. The giant mud crab captured by the fishermen are counted, identified by sex, measured in carapace width and weighed. The results showed that giant mud crab (Scylla serrata) caught in February - April 2019 obtained 300 individuals consisting of 202 males and 98 females. The highest average carapace width ranges from $9.8 \mathrm{~cm}$ in catches in February. Relationship between carapace and weight of giant mud crab (Scylla serrata) both male and female showed negative allometric growth patterns.
\end{abstract}

Keywords : Carapace - weight relationship; growth; morphometric; Scylla serrata

\section{PENDAHULUAN}

Kepiting bakau (Scylla serrata) adalah salah satu komoditas sumberdaya perikanan yang sangat potensial untuk dikembangkan dan memiliki nilai ekonomis yang tinggi di Indonesia, 
terutama kepiting yang sudah matang gonad dan sudah dewasa serta gemuk. Menurut Catacutan (2002) kepiting bakau (Scylla serrata) telah dikenal baik di pasaran dalam negeri maupu luar negeri karena rasa dagingnya yang lezat dan tinggi akan nilai gizinya. Berdasarkan hasil analisis proksimat diketahui bahwa daging kepiting kakau mengandung protein 44,85-50,58\%, lemak 10,52-13,08\% dan energi 3.579-3.724 kkal/g (Pramudya et al. 2013).

Menurut data Kementerian Kelautan dan Perikanan dalam Akbar et al (2016), menyatakan bahwa selama periode tahun 2005-2011, permintaan kepiting segar di pasar dunia yang cukup tinggi khususnya berasal dari Amerika Serikat yang memang merupakan negara tujuan utama ekspor produk-produk kepiting Indonesia. Volume ekspor kepiting dari Indonesia terus berfluktuasi sepanjang tahun 2005 hingga tahun 2010. Pada tahun 2005 volume ekspor mencapai 12,6 ribu ton kemudian terus mengalami penurunan pada tahun-tahun berikutnya hingga hanya sebesar 7,7 ribu ton pada tahun 2009. Volume ekspor kepiting Indonesia baru kembali mengalami peningkatan pada tahun 2010 yakni sebesar 9,3 ribu ton. Tahun 2011 permintaan ekspor tertinggi sebanyak 4 ribu ton ke negara China.

Sumber daya kepiting bakau (Scylla serrata) dipengaruhi oleh natalitas dan mortalitas. Selain itu, aktivitas penangkapan juga akan mempengaruhi keberadaan kepiting bakau (Scylla serrata) di perairan. Penggunaan alat tangkap, proses, dan operasi penangkapan serta dampak terhadap habitat akan sangat kuat pengaruhnya (Larosa et al. 2013). Adanya Peraturan Menteri Kelautan dan Perikanan Nomor 1/PERMEN-KP/2015 yang salah satu isinya mengatur tentang penangkapan kepiting bakau (Scylla serrata) dengan ukuran lebar karapas $>15 \mathrm{~cm}$, yang kemudian dilengkapi dengan surat edaran Nomor 18/MEN-KP/I/2015 yang mengatur penangkapan kepiting bakau (Scylla serrata) dengan ukuran berat $200 \mathrm{~g}$ dan ukuran berat kepiting bakau (Scylla serrata) yang ditetapkan pada bulan Januari 2016 dan seterusnya yaitu $>350$ g yang menjadikan pengelolaan kepiting bakau (Scylla serrata) secara tepat menjadi hal yang penting.

Penelitian ini bertujuan untuk mengetahui prosentase kelamin kepiting bakau (Scylla serrata), distribusi lebar karapas, dan hubungan lebar karapas - berat kepiting bakau (Scylla serrata) yang ditangkap di daerah Kecamatan Wedung, Demak. Diharapkan dapat memberi sumber informasi berupa komposisi Kepiting bakau (Scylla serrata), distribusi lebar karapas, dan hubungan lebar karapas - berat Kepiting bakau (Scylla serrata) di daerah Kecamatan Wedung, Demak. Selain itu sebagai bahan pertimbangan dalam menentukan kebijakan yang tepat bagi pengelolaan perikanan Kepiting bakau (Scylla serrata), sehingga kesetimbangan populasi Kepiting bakau (Scylla serrata) dapat terpelihara dengan baik. Proses penangkapannya dapat mengikuti norma konservasi dalam mengusahakan hasil yang optimal dengan tetap memperhatikan kelestariannya

\section{MATERI DAN METODE}

Materi yang digunakan dalam penelitian ini adalah sampel kepiting bakau (Scylla serrata) yang diambil nelayan pada area tambak dan laut daerah Kecamatan Wedung, Demak. Penelitian ini dilakukan selama bulan Februari - April dengan tiap bulannya menggunakan 100 sampel dan diambil secara acak. Semua kepiting bakau (Scylla serrata) yang tertangkap diukur (lebar, dan panjang karapas), ditimbang (berat), dan dibedakan jenis kelamin (betina dan jantan).

Pengambilan data untuk sampling dilakukan dengan cara mendaratkan kepiting bakau yang sudah ditangkap di daerah Kecamatan Wedung Demak. Sampel yang sudah terkumpul dilakukan pendataan panjang, lebar, dan berat dari tubuh kepiting bakau yang didapatkan. Prosedur dalam pengukuran panjang dan lebar atau morfometri digunakan jangka sorong dengan tingkat ketelitian $0,01 \mathrm{~mm}$, kemudian digunakan neraca analitik untuk mengukur berat tubuh dari kepiting bakau (Overton et al., 1997).

Pengukuran berat tubuh menggunakan neraca analitik dan pengukuran lebar karapas dengan menggunakan penggaris ketelitian $1 \mathrm{~mm}$ dan pengukuran aspek meristik secara visual serta pengolahan data lebar karapas dengan berat untuk pola pertumbuhan. Indeks kelimpahan relatif kepiting bakau (Scylla serrata) dapat diketahui dengan rumus, serta analisis mengenai hubungan lebar karapas dan berat dapat digunakan untuk mempelajari pola pertumbuhan. Hubungan lebar karapas dengan berat berdasarkan Effendie (2000). 


\section{HASIL DAN PEMBAHASAN}

Kepiting bakau (Scylla serrata) yang diteliti selama bulan Februari - April 2019 berjumlah 300 individu yang terdiri dari 98 individu betina dan 202 individu jantan, kelimpahan relatif sampel dari 100 individu Scylla serrata pada bulan Februari terdiri dari 34 individu berjenis betina dan 66 individu berjenis jantan. Pada bulan Maret total sampel Scylla serrata dari keseluruhan terdiri dari 35 individu berjenis kelamin betina dan 65 individu berjenis kelamin jantan. Sedangkan pada bulan April total tangkapan Scylla serrata dari keseluruhan terdiri dari 29 individu berjenis kelamin betina dan 71 individu berjenis kelamin jantan. Kepiting jantan ditemukan lebih banyak dibandingkan dengan kepiting betina pada setiap bulan pengamatan, hal ini kemungkinan disebabkan oleh migrasi kepiting betina. Menurut Pratiwi (2011), Kepiting Bakau betina akan bermigrasi ke perairan laut atau menjauhi pantai untuk mencari perairan yang parameter lingkungannya (terutama suhu dan salinitas) cocok sebagai tempat memijah.

Menurut Irsyad (komunikasi pribadi), umumnya nelayan mengenal tiga musim penangkapan yaitu musim Barat (Puncak), musim Peralihan, dan musim Timur (Paceklik). Musim Barat (Puncak) terjadi pada bulan Januari - Mei, sedangkan pada musim Peralihan terjadi pada bulan Juni September, dan pada musim Timur (Paceklik) terjadi pada bulan Oktober - Desember. Kepiting bakau memijah sepanjang tahun dengan memiliki 4 musim puncak pemijahan yaitu, musim barat terjadi di bulan Desember - Februari, musim peralihan I di bulan Maret - Mei, musim Timur di bulan Juni - Agustus dan peralihan II di bulan September - November (Endrawati et al. 2004). Hasil yang didapatkan pada penelitian ini sama dengan penelitian Sentosa dan Syam (2011) di Perairan Mayangan, Jawa Barat; Tirtadanu dan Umi (2018) Di Perairan Sebatik, Kalimantan Utara, yang menyatakan komposisi kepiting bakau didominasi oleh kepiting jantan.

Distribusi frekuensi lebar karapas dapat digunakan untuk mengetahui modus, ukuran karapas tertinggi dan terendah dari Scylla serrata (Hoek et al. 2015). Berdasarkan hasil pengukuran lebar karapas Scylla serrata diperoleh 10 kelas ukuran lebar karapas. Pembagian kelas ukuran lebar karapas berdasarkan jarak interval ukuran panjang terendah yang didapatkan yaitu $5.5 \mathrm{~cm}$ dan ukuran tertinggi sebesar $12.5 \mathrm{~cm}$ dengan jarak $1 \mathrm{~cm}$ untuk tiap ukuran kelas, seperti yang terlihat pada Gambar 1.

Berdasarkan kisaran ukuran lebar karapas kepiting bakau (Scylla serrata) betina dan jantan yang tertangkap di Daerah Kecamatan Wedung Demak, dapat diketahui bahwa kepiting bakau (Scylla serrata) hasil tangkapan bulan Februari memiliki kisaran rata - rata lebar karapas tertinggi dibandingkan pada bulan Maret dan April, hal tersebut ditunjukkan dengan adanya pergeseran modus kelas pada kepiting bakau (Scylla serrata) pada bulan Februari (Gambar 2). Ukuran lebar karapas yang bervariasi ini diduga dipengaruhi oleh waktu penangkapan yang berhubungan dengan masa reproduksi, dimana masa reproduksi kepiting bakau berlangsung sepanjang tahun dan puncaknya pada bulan Januari - Mei (Sianturi et al. 2015). Menurut Le Vay (2001), hal ini disebabkan oleh produktivitas perairan pesisir yang tinggi terjadi pada musim penghujan. Kepiting bakau (Scylla serrata) yang tertangkap pada musim penghujan memiliki ukuran lebar karapas paling besar.

Menurut Tahmid et al. (2015), lebar karapas pada kepiting bakau (Scylla serrata) betina cenderung memiliki ukuran lebih besar bila dibandingkan ukuran karapas kepiting bakau (Scylla serrata) jantan. Pada berat tubuh yang sama, ukuran kepiting jantan cenderung lebih kecil daripada kepiting betina. Hal ini dikarenakan pada kepiting jantan dewasa memiliki ukuran capit yang lebih kecil bila dibandingkan dengan kepiting betina (Sagala et al. 2013). Analisis hubungan lebar karapas - berat Scylla serrata digunakan dengan tujuan untuk melihat pola pertumbuhan Scylla serrata hasil tangkapan di daerah Kecamatan Wedung, Demak. Hasil analisis hubungan lebar karapas - berat Scylla serrata.

Hasil tangkapan kepiting bakau pada penelitian ini dengan modus kelas lebar karapas 7.7$8.9 \mathrm{~cm}$ tergolong kecil, jika dibandingkan dengan ukuran yang boleh ditangkap berdasarkan PERMEN-KP No. 1 Tahun 2015 yaitu sebesar $15 \mathrm{~cm}$. Menurut Herliany dan Zamidal (2015), jika aktifitas penangkapan ini diteruskan maka proses restocking di alam akan terganggu sehingga dapat mengakibatkan kepunahan kepiting bakau di alam.

Nilai b yang didapatkan secara umum pada kepiting bakau (Scylla serrata) baik pada kelamin betina dan jantan yang tertangkap oleh nelayan daerah Kecamatan Kedungkarang 
Wedung Demak pada bulan Februari - April 2019 nilai $b<3$ menunjukan pertumbuhan yang bersifat allometrik negatif. Dapat dilihat pada Gambar 2. menunjukkan bahwa variabel lebar karapas memiliki pengaruh terhadap variabel berat. Hubungan lebar karapas dan berat pada kepiting bakau (Scylla serrata) yang berasal dari hasil tangkapan di Daerah Kecamatan Wedung Demak bulan Februari - April 2019.

Kepiting bakau (Scylla serrata) jantan memiliki sifat seksualitas dimorfisme, dimana kepiting bakau jantan memiliki bobot yang lebih berat dibandingkan kepiting bakau betina pada ukuran lebar karapas yang sama, hal ini disebabkan oleh adanya perbedaan aktivitas makan rajungan jantan lebih tinggi dibandingkan rajungan betina, selain itu rajungan betina membutuhkan energi dalam proses perkembangan gonad sehingga aktivitas makan rajungan betina akan cenderung turun (Anam et al. 2018). Pola pertumbuhan kepiting bakau (Scylla serrata) jantan allometrik negatif dikarenakan pada kepiting jantan molting lebih jarang terjadi dan asupan makanannya banyak digunakan untuk memanjangkan dan membesarkan capit (Siregar et al. 2017).
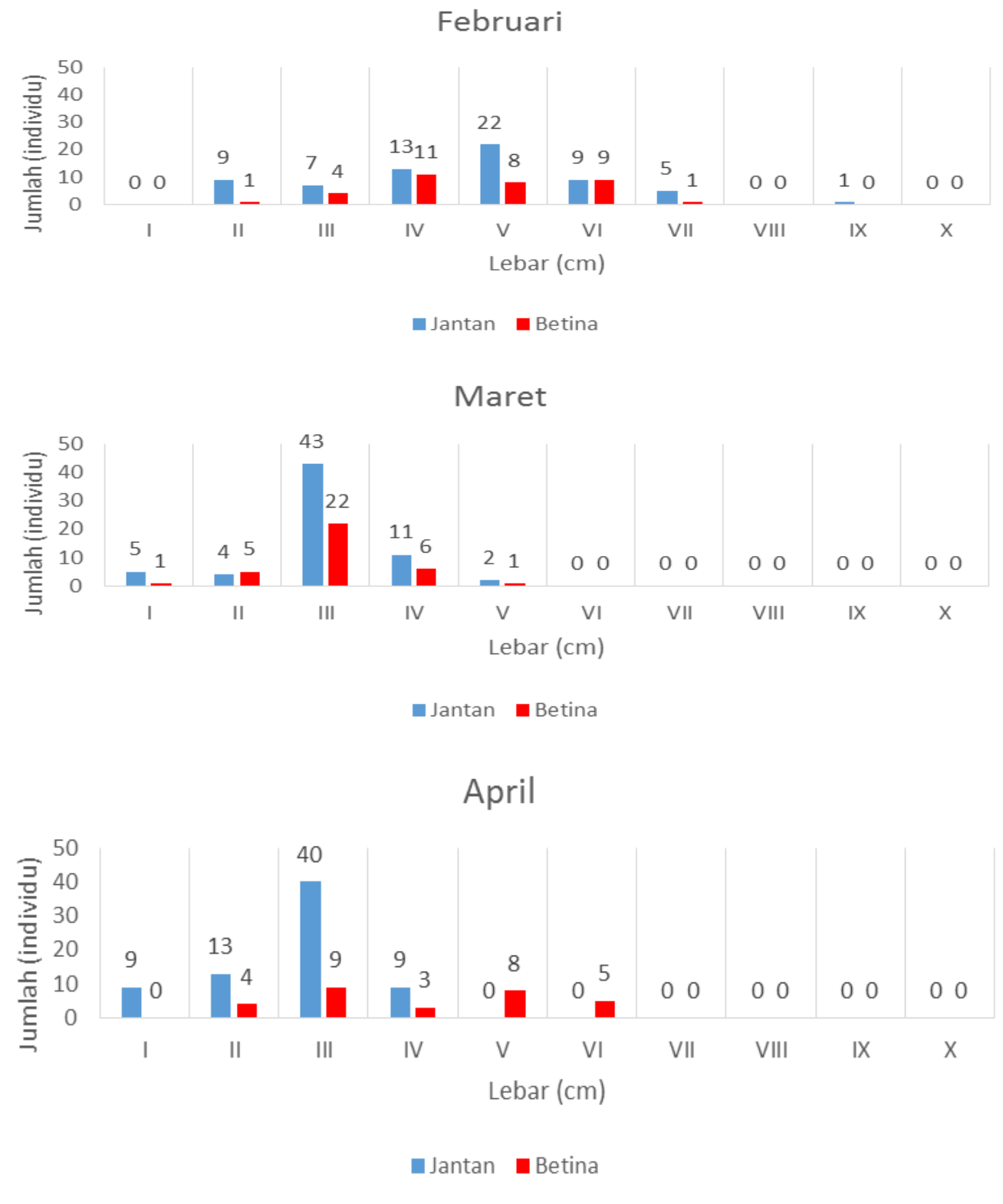

Gambar 1. Pergeseran Distribusi Kelas Lebar Karapas Scylla serrata Hasil Tangkapan di Kecamatan Wedung, Demak Bulan Februari - April 2019.

Keterangan : I = 5.5-6.5; II = 6.6-7.6 $\mathrm{III}=7.7-8.7 ; \mathrm{IV}=8.8-9.8 ; \mathrm{V}=9.9-10.9 ; \mathrm{VI}=$ $11.0-12.0 ; \mathrm{VII}=12.1-13.1 ; \mathrm{VIII}=13.2-14.2 ; \mathrm{IX}=14.3-15.3 ; \mathrm{X}=15.4-16.4$ 
Februari

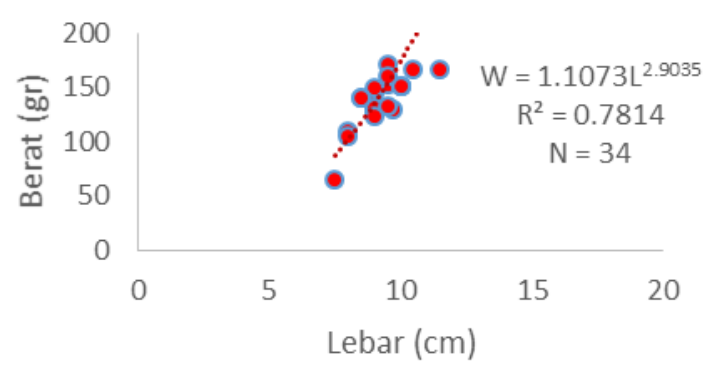

Maret

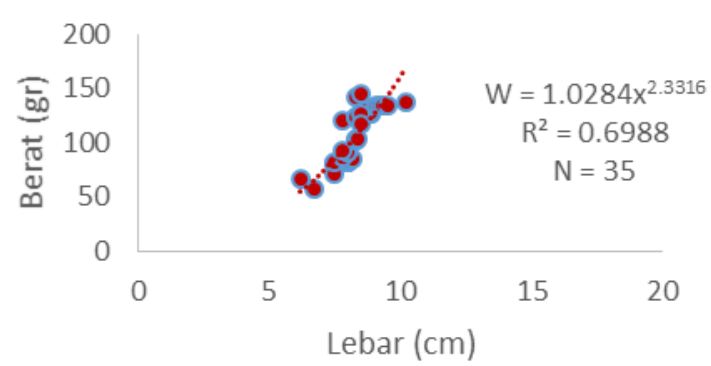

April

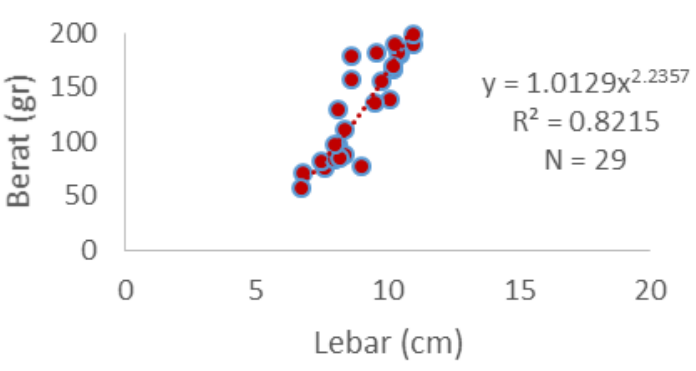

Februari

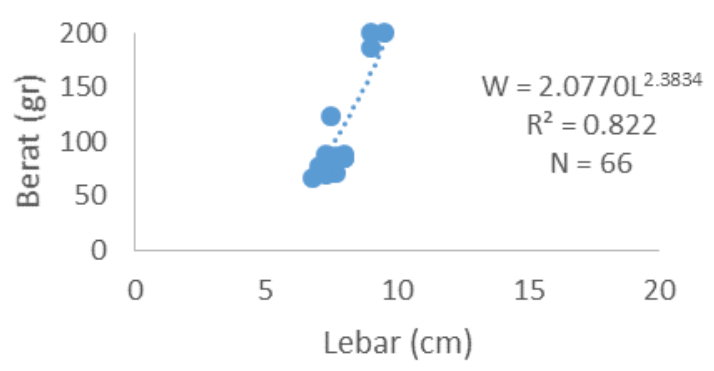

Maret

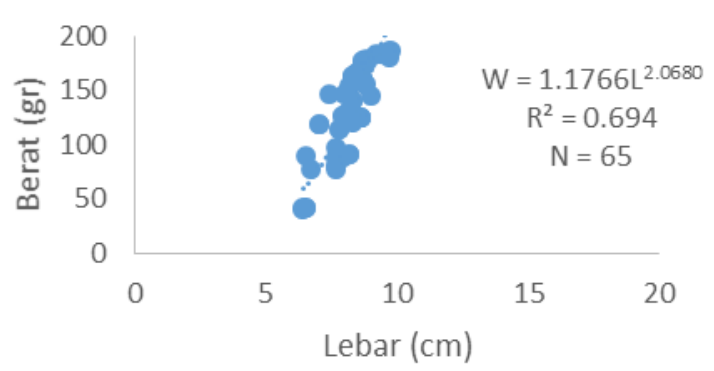

April

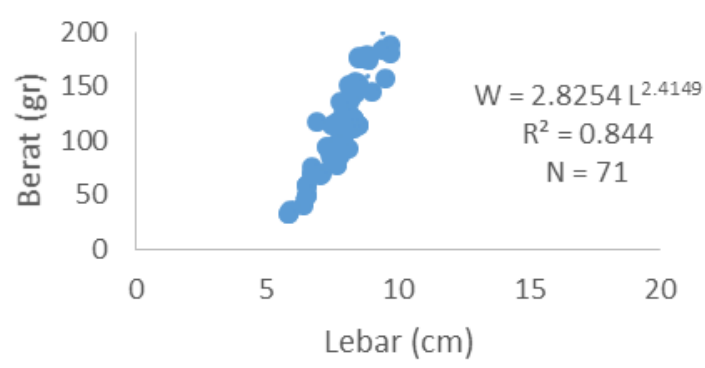

Gambar 2. Hubungan Lebar Karapas dan Berat Kepiting Bakau (Scylla serrata) Betina (oranye) dan Jantan (biru) di Kecamatan Wedung, Demak

Menurut Yunus et al. (2018), bahwa Kepiting Bakau betina yang memiliki pola pertumbuhan allometrik negatif disebabkan karena Kepiting Bakau betina menggunakan asupan makanan lebih banyak untuk moulting dan proses kematangan gonad, sehingga pertumbuhan Kepiting Bakau betina cenderung lebih ke arah lebar karapas karena kepiting betina akan moulting setiap akan melakukan proses kopulasi.

\section{KESIMPULAN}

Komposisi Kepiting Bakau (Scylla serrata) di Kecamatan Wedung Demak di dominasi oleh Kepiting Bakau (Scylla serrata) berjenis jantan. Distribusi frekuensi lebar karapas Kepiting Bakau (Scylla serrata) di Kecamatan Wedung yang tertangkap pada bulan Februari rata - rata memiliki ukuran lebar karapas, baik betina dan jantan tertinggi sebesar $9.8 \mathrm{~cm}$ dan $9.7 \mathrm{~cm}$ bila dibandingkan pada bulan Maret sebesar $8.2 \mathrm{~cm}$ pada betina dan jantan, sedangkan bulan April sebesar $9.2 \mathrm{~cm}$ untuk betina dan $7.8 \mathrm{~cm}$ untuk jantan. Hubungan lebar karapas - berat Kepiting Bakau (Scylla serrata) betina dan jantan menunjukkan pola pertumbuhan allometrik negatif. 


\section{DAFTAR PUSTAKA}

Akbar, W., Yusnaini, \& Wellem, H.M. 2016. Pertumbuhan Kepiting Bakau (Scylla serrata) yang Diberi Pakan Usus Ayam yang Dikukus dan Ikan Rucah. Media Akuatika. 1(3):190-196.

Anam, A., Sri, R. \& Retno, H. 2018. Sebaran Ukuran Lebar Karapas Dan Berat Rajungan (Portunus pelagicus) Di Perairan Betahwalang Demak. Journal of Marine Research. 7(4): 239-247.

Catacutan, M.R. 2002. Growth and Body Composition of Juvenile Mud Crab, Scylla serrata, Fed Different Dietary Protein and Lipid Levels and Protein to Enegry Ratio. Aquaculture, 208: 113-123.

Effendie, M. I. 2000. Metode Biologi Perikanan. Yayasan Pustaka Nusatara, Yogyakarta. $163 \mathrm{hlm}$.

Endrawati, H., M. Zainuri, C. A. Suryono dan Suryono. 2004. Pengaruh Kepadatan Terhadap Tingkat Kematangan Gonad dan Fekunditas Kepiting Bakau (Scylla serrata) pada Kultivasi di Tambak Garam. IImu Kelautan, 9(4):196-201.

Herliany, N.E. \& Zamdial. 2015. Hubungan Lebar Karapas dan Berat Kepiting Bakau (Scylla spp) Hasil Tangkapan di Desa Kahyapu Pulau Enggano Provinsi Bengkulu. Jurnal Kelautan, 8(2):89-94.

Hill, B.J. 1975. Abudance, Breeding and Growth of The Crab Scylla Serrata in Two South African Estuaries. Marine Biology, 32:119-126.

Hoek, F., Razak, A.D., Sururi, M., \& Yampapi, M. 2015. Distribusi Frekuensi Ukuran Lebar Karapaks dan Berat Kepiting Bakau (Scylla serrata) dengan Alat Tangkap Bubu lipat di Perairan Kabupaten Teluk Bintuni, Papua Barat. Jurnal Airaha. 4(2):57-64.

Larosa, R., Hendrarto, B. \& Nitisupardjo, M. 2013. Identifikasi Sumberdaya Kepiting Bakau (Scylla sp.) yang didaratkan di TPI Kabupaten Tapanuli Tengah. Journal of Management of Aquatic Resources, 2(3):180-189.

Le Vay. 2001. Ecology and Management of Mud Crab Scylla spp. Asian Fisheries Science. Proceedings of the International Forum on the Culture of Portunid Crabs: Manila, Philiphines 2001 Asian Fisheries Society. Manila. 101-111 p.

Overton, J.L., Macintosh, D.J. \& Thorpe, R.S. 1997. Multivariate Analysis of The Mud Crab Scylla serrata (Brachyura: Portunidae) from Four Locations in South East Asia. Marine Biology, 8p.

Pramudya, T.P., Chrisna A.S \& Endang, S. 2013. Kandungan Kolesterol Kepiting Bakau (Scylla serrata) Jantan Dan Betina Pada Lokasi Yang Berbeda . Journal of Marine Research. 2(1): 48-53.

Pratiwi, M. 2011. Biologi Kepiting Bakau (Scylla spp.) Di Perairan Indonesia. Oseana. 36(1):1-11.

Sagala, L.S.S., Idris, M. \& Ibrahim, M.N. 2013. Perbandingan Pertumbuhan Kepiting Bakau (Scylla serrata) Jantan dan Betina pada Metode Kurungan Dasar. Jurnal Mina Laut Indonesia., $3(12): 46-54$.

Sentosa, A.A. \& Syam, A.R. 2012. Pertumbuhan dan Mortalitas Kepiting Bakau, Scylla tranquebarica Fabricius, 1798 di Perairan Pantai Mayangan, Kabupaten Subang, Jawa Barat. Dalam: Seminar Nasional Tahunan IX Hasil Penelitian Perikanan dan Kelautan Tanggal 14 Juli 2012. Yogyakarta, pp. 1-10.

Sianturi, A., Basyuni, M. \& Apandy, Z. 2015. Tingkat Kematangan Gonad Kepiting Bakau (Scylla serrata) di Kawasan Hutan Mangrove Sicanang Kecamatan Medan Belawan Sumatera Utara. Aquacoastmarine, 12(2):38-47

Siregar, D.S., Sitorus, H. \& Suryanti, A. 2017. Karakter Morfometrik dan Meristik Kepiting Bakau (Scylla serrata) di Perairan Mangrove Kampung Sentosa Barat Kelurahan Belawan Sicanang Kecamatan Medan Belawan. Aquacoastmarine, 5(4):128-137.

Tahmid, M., Fahrudin, A. \& Wardiatno, Y. 2015. Kajian Struktur Ukuran dan Parameter Populasi Kepiting Bakau (Scylla serrata) di Ekosistem Mangrove Teluk Bintan, Kepulauan Riau. Jurnal Biologi Tropis, 15(2):93-106.

Tirtadanu dan U. Chodrijah. 2018. Parameter Populasi Dan Tingkat Pemanfaatan Kepiting Bakau (Scylla serrata Forsskal, 1775) Di Perairan Sebatik, Kalimantan Utara. J.Lit.Perikan.Ind. 24(3):187 - 196.

Yunus, B., Suwarni, \& Santy, A.I 2018. Hubungan Lebar Karapas Bobot, Faktor Kondisi, dan Kelimpahan Kepiting Bakau Scylla serrata Forsskal, 1775; di Kawasan Pengembangan Silvofishery Jalur Tanggul, Kabupaten Maros. Prosiding Simposium Nasional Kelautan dan Perikanan. 